\section{Paweł Wańczyk}

Uniwersytet Papieski Jana Pawła II w Krakowie paw-wan@wp.pl

DOI: http://dx.doi.org/10.12775/BPTh.2016.029

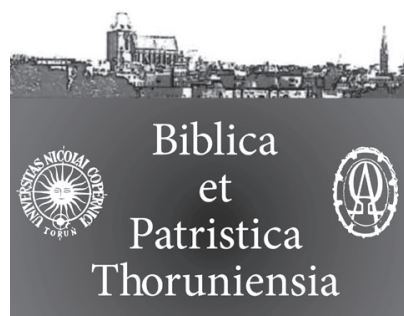

9 (2016) 3: 199-209

ISSN (print) 1689-5150

ISSN (online) 2450-7059

\title{
Wychowawcze wskazówki dla rodziców w Ewangeliach
}

\section{Pedagogical directions for parents according to the Gospels}

Streszczenie. W obliczu nieustannych przemian społecznych konieczne jest by chrześcijanie na nowo podejmowali refleksję nad zagadnieniem wychowania dzieci i młodzieży. Kwestia ta powinna być rozważana również w świetle Ewangelii, gdyż to One są jednym z najważniejszych czynników kształtujących życie wyznawców Chrystusa. I tak, w Ewangeliach dzieciństwa Jezusa godna zauważenia jest postawa Józefa oraz Maryi, którzy dzięki głębokiej relacji z Bogiem właściwie kierowali wychowaniem syna. W scenach ukazujących podejście dorosłego już Jezusa do dzieci, widać, że chętnie dopuszczał je do siebie, był wobec nich serdeczny, a co więcej, potrafił dostrzec w dziecku pewne naturalne, dobre postawy, które dał swoim uczniom jako wzór do naśladowania.

\begin{abstract}
Due to the continuous social transformations Christians must once again take up the reflection about education of children and youth. This issue should be also considered on the basis of the Gospels, that are one of the most important sources for Christ's believers. In the "infancy Gospels" of Jesus, it is worth to notice the attitude of Joseph and Mary, who thanks to a deep relationship with God properly guided the upbringing their son. In scenes depicting adult Jesus's approach to children, everyone can see that he willingly permitted them to himself, he was warm to them and what more could see in the child some natural good attitudes, which he gave to his disciples as a model to follow.
\end{abstract}

Słowa kluczowe: wychowanie; pedagogia; dzieci; młodzi; rodzice; ojciec; matka; rodzina; relacje rodzinne.

Keywords: upbringing; pedagogy; children; young people; parents; father; mother; family; household relationships. 
$\mathrm{D}$ okonujące się w ostatnich stuleciach przemiany cywilizacyjno-kulturowe obligują chrześcijan do podjęcia refleksji nad obecną sytuacją społeczną. Przynaglają również do określenia właściwych postaw, a także działań, jakie w tych nowych warunkach powinny cechować prawdziwych uczniów Chrystusa. Takie niezmiernie istotne zadanie postawione jest szczególnie przed katolickimi rodzicami, gdyż to właśnie oni są odpowiedzialni za powoływanie do życia i wychowywanie dzieci, tak aby te odważnie świadczyły o miłości Boga oraz ofiarnie służyły Kościołowi. Obowiązek formacji dorastających młodych ludzi nie jest łatwy, ponieważ czyha na nich wiele niebezpieczeństw, wśród których są m.in. groźne prądy myślowe takie jak ateizacja, konsumpcjonizm, seksualizacja, czy mocno promowany w ostatnim czasie egocentryzm. Z tego względu rzeczą bardzo przydatną dla chrześcijańskich małżonków, jak i innych osób zajmujących się kształtowaniem postaw i wartości u przyszłych pokoleń, może być ponowne spojrzenie na kwestię wychowania w świetle Biblii, a dokładniej mówiąc Ewangelii.

Ewangelie, jako księgi Nowego Testamentu, są przekazem Dobrej Nowiny o Jezusie Chrystusie oraz głoszeniem Jego orędzia o przybliżającym się Królestwie Bożym (por. Mk 1,15). W związku z tym, że właśnie to było główną misją Jezusa, trudno doszukać się w Jego nauce konkretnych wskazań dotyczących niektórych dziedzin życia człowieka ${ }^{1}$ - w tym także kwestii odnoszących się do wychowania młodych ludzi. Na szczęście z pomocą przychodzą niektóre wydarzenia opisane w Ewangeliach, przybliżające zdarzenia z dzieciństwa Jezusa i omawiające podejście dorosłego już Chrystusa do dzieci. I właśnie analiza tych dwóch sfer z życia Jezusa pozwoli odkryć przekaz Ewangelii, odnośnie zagadnienia postawionego w tytule niniejszego artykułu.

\section{Wydarzenia z dzieciństwa Jezusa}

Na początku warto spojrzeć na tzw. Ewangelie dzieciństwa Jezusa, które obejmują pierwsze rozdziały Mt i Łk. Z tej racji, iż opowiadają one o niezwykłych, ale też niezrozumiałych wydarzeniach związanych z narodzeniem jednej konkretnej osoby - Jezusa - trudno z nich wyciągnąć wiele ogólnych pouczeń. We fragmentach, mówiących o Jego wcieleniu i przyjściu na świat warto zwrócić uwagę na to, iż to dzięki głębokiej więzi z Bogiem oraz otwartości na wypełnianie Jego woli, Maryja z Józefem przezwyciężyli pojawiające się trudności ${ }^{2}$ (np. podejrzenie zdrady - Mt 1, 18-25; ubogie warunki, w jakich dokonał się

1 Por. J. Szlaga, Główne tematy w Ewangelii Jezusa Chrystusa, s. 103n.

2 Por. A. Paciorek, Ewangelia według świętego Mateusza rozdziały 1-13, s. 97n. 
poród - Łk 2,4-7; konieczność ucieczki do Egiptu - Mt 2,13-23) i stworzyli Jezusowi bezpieczny i szczęśliwy dom rodzinny ${ }^{3}$.

Z perykop, mówiących o dzieciństwie Pana, najbogatszy materiał dla omawianego tematu daje scena pozostania dwunastoletniego Jezusa w Jerozolimie i odnalezienia Go przez Maryję i Józefa (Łk 2, 41-51). Zaczyna się ona stwierdzeniem, że "rodzice Jego chodzili co roku do Jerozolimy na Święto Paschy” (Łk 2, 41), po czym padają słowa, iż zgodnie ze zwyczajem świątecznym udali się tam również w tym roku, w którym Jezus miał lat dwanaście. Wyakcentowanie corocznego zwyczaju pielgrzymowania Maryi i Józefa pozwala przypuszczać, że nie był to pierwszy raz, gdy mały Jezus był w Jerozolimie, a wzmianka o wieku chłopca służy niewątpliwie nakreśleniu tła dla wydarzeń opisanych w następnych wersetach ${ }^{4}$. Dodać trzeba, że obowiązek pielgrzymowania do Miasta Świętego dotyczył tylko mężczyzn i to dopiero od trzynastego roku życia. Zatem rodzice Jezusa, zabierając Go wcześniej niż wymagało tego Prawo, dbali o wczesne wdrażanie syna w zwyczaje związane z życiem religijnym ${ }^{5}$, a co więcej swoją postawą dawali Mu przykład, że w pobożności człowiek nie powinien być minimalistą. Świadczy o tym po pierwsze pielgrzymka Maryi na Paschę do Jerozolimy - podczas gdy kobiety nie miały takiego obowiązku, a po drugie dłuższy pobyt w Mieście Dawida niż to było konieczne. Bowiem część pątników powracała do swoich miejsc zamieszkania zaraz po Passze, która była pierwszym dniem z całotygodniowego Święta Przaśników, natomiast jak wskazuje tekst Ewangeliii ${ }^{6}$ Święta Rodzina przebywała w Jerozolimie kilka dni, a wręcz może nawet przez cały świąteczny tydzień ${ }^{7}$.

Kolejne ważne dla niniejszego opracowania słowa pojawiają się kilka wersetów dalej, po opisie tego jak wracający Józef i Maryja spostrzegli nieobecność Jezusa wśród pielgrzymów ${ }^{8}$, i gdy po trzydniowych poszukiwaniach odnaleźli

3 Por. J. Królikowski, Biblijne miejsce Józefologii, s. 47n; R. Gauthier, Święty Józef w Historii Zbawienia, s. 33-36.

4 Por. J. Nolland, Luke 1-9:20, s. 129.

5 J. Łach uważa wręcz, że właśnie ta myśl jest najważniejszym przesłaniem tej perykopy. Wspomniany autor mówi: „względy katechetyczne więc stanowiły główną rację zamieszczenia tego opisu wśród opowiadań o Jezusie z czasów Jego młodości”. J. Łach, Ewangelie dziecięctwa - historia czy legenda?, s. 316.

6 Łukasz, podejmując temat powrotu Józefa i Maryi (por. Łk 2,43), stosuje wyrażenie

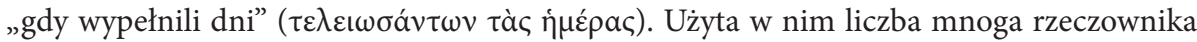

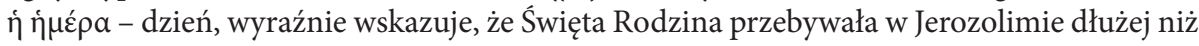
przez samą Paschę.

7 Por. F. Mickiewicz, Ewangelia według świętego Łukasza rozdziały 1-11, s. 198n.

8 Komentatorzy na różny sposób próbują wytłumaczyć to, że Józef z Maryją nie zauważyli braku Jezusa wśród pielgrzymów. Niektórzy wskazują, iż kobiety, z racji tego, iż były 
Go siedzącego w świątyni i rozmawiającego z uczonymi w Piśmie. Wówczas to Maryja skierowała do Niego pytanie: „Synu, czemuś nam to uczynił? Oto ojciec Twój i ja ${ }^{9} \mathrm{z}$ bólem serca szukaliśmy Ciebie" (Łk 2,48). Wypowiedzenie takiego wyrzutu wydaje się być czymś naturalnym w sytuacji, gdy rodzice doświadczyli cierpienia i lęku spowodowanego zaginięciem dziecka ${ }^{10}$, i to pomimo tego, że ich pierwszą reakcją na odnalezienie Jezusa wśród religijnych nauczycieli były zdziwienie i zachwyt ${ }^{11}$, zapewne spowodowane wykazaną mądrością ich Syna. Jednakże te wymówki wobec Jezusa nie doprowadziły do rozwikłania tej trudnej sytuacji - a wręcz przeciwnie - wywołały dość zagadkową odpowiedź Jezusa, która ukazała w pełni to, niezawinione przez żadną ze stron, niezrozumienie $^{12}$ : „Czemuście Mnie szukali? Czy nie wiedzieliście, że powinienem być w tym, co należy do mego Ojca” ( $Ł$ k 2,49). Ta nieco tajemnicza i bardzo głęboka odpowiedź z pewnością odnosi się do misji Jezusa jako Mesjasza, i mówi bardziej o Jego Boskiej samoświadomości i tożsamości, niż o sytuacji zgubienia Go przez Jego rodziców ${ }^{13}$. Pomimo to z tych słów Jezusa można też wyciągnąć naukę związaną z omawianym tematem. A mianowicie swoją odpowiedzią wskazuje On, że każdy człowiek ma pełnić wolę Boga Ojca, żyć ku Jego chwale, natomiast rola rodziców jest poniekąd drugorzędna ${ }^{14}$. Co prawda, są oni współpracownikami w dziele stwórczym Boga, odpowiadają za wycho-

słabsze fizycznie i chodziły wolniej, wyruszały wcześniej niż mężczyźni, i dlatego obie grupy spotykały się dopiero pod wieczór. W takich to okolicznościach Maryja mogła myśleć, że Jezus jest z Józefem, a Józef, że Jezus jest z Maryją. Inni jako powód zaistniałej sytuacji podają zaufanie rodziców do Jezusa i Jego zaradności, i sugerują, że Józef z Maryją na pewno sądzili, iż ich dziecko pielgrzymuje wśród innych pątników, pochodzących z ich okolic. Por. S.O. Abogunrin, Ewangelia według św. Łukasza, s. 1247; C.S. Keener, Komentarz historyczno-kulturowy do Nowego Testamentu, s. 130.

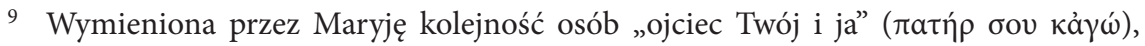
może wskazywać, jak sugerują niektórzy komentatorzy, na pierwszeństwo ojca we władzy rodzicielskiej. Por. T. Herrmann, Obowiązki rodziców względem dzieci w Nowym Testamencie, s. 46. Jednakże taka kolejność wydaje się bardziej ukazywać fakt, iż to właśnie ojciec powinien być wzorcem i autorytetem dla dorastającego chłopca.

10 Por. L.T. Johnson, The Gospel of Luke, s. 59.

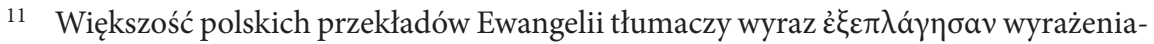
mi „zdziwili się bardzo”, „dziwili się”, jednak takie sformułowania nie oddają głębi użytego tu czasownika, który „w Ewangeliach ma zawsze charakter religijny oraz wyraża podziw i zachwyt spowodowany nauką i cudami Jezusa, Jego mądrością i płynącą z Niego mocą". F. Mickiewicz, Ewangelia według świętego Łukasza rozdziały 1-11, s. 200.

12 Por. A. Jankowski, Początki Łukaszowej Mariologii, s. 328.

13 Por. K. Romaniuk, A. Jankowski, L. Stachowiak, Komentarz praktyczny do Nowego Testamentu, t. 1, s. 283n.

14 Por. A. Jankowski, Matka Mesjasza pierwowzorem Kościoła, s. 216. 
wanie danego im potomstwa, ale powierzone im dziecko nie jest ich własnością, a jego właściwym powołaniem jest bycie w łączności z Bogiem i pełnienie tych zadań, które Najwyższy dla niego przewidział. Ta kwestia może wydawać się niezbyt istotna dopóki dziecko jest małe, jednak, gdy młoda osoba nabiera samodzielności i zaczyna decydować o swoim życiu to niewłaściwa, zaborcza postawa rodziców może powodować konflikty. Trzeba też zauważyć, że zdrowe podejście ojca i matki, szanujące wolność i autonomię dziecka, oprócz wykształcenia odpowiedzialności u ich pociech, okazuje się też być korzystne dla nich samych, zwłaszcza w niełatwej sytuacji odejścia syna lub córki z domu, czy to $\mathrm{z}$ racji założenia własnej rodziny, czy też realizacji powołania na innej drodze, również wymagającej opuszczenia rodziców ${ }^{15}$.

Jednakże z omawianego fragmentu nie można jednostronnie wnioskować, że formację młodego człowieka należy oprzeć tylko na jego zdaniu, na tym, w jakim kierunku on chce dążyć. Chociaż dwunastoletni Jezus faktycznie wyraźnie ukazał Józefowi i Maryi, co jest Jego powołaniem, to jednak jak mówią kolejne słowa Ewangelii: „Potem poszedł z nimi i wrócił do Nazaretu; i był im poddany" (Łk 2,51a). Tak więc nie można mówić tu o jakimkolwiek Jego nieposłuszeństwie, co w sposób szczególny podkreśla użyte wyrażenie „był im

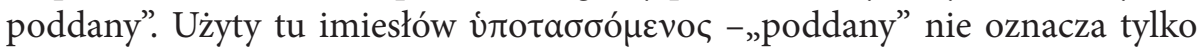
posłuchu jaki dziecko powinno mieć wobec ojca i matki, lecz zupełne poddanie jednej osoby względem innej, której przynależy władza i autorytet. Zatem w przypadku Jezusa należy mówić o Jego całkowitym posłuszeństwie, które jest doskonałym wypełnieniem przykazania czci rodziców (Wj 20,12) i stanowi wzór do naśladowania dla wszystkich dzieci ${ }^{16}$.

Zbierając więc to co powiedziano, należy stwierdzić, że w wychowaniu potrzebne jest właściwe zrównoważenie pomiędzy kształtowaniem młodego człowieka według tego co rodzice uznają dla niego za dobre, a odpowiednią dozą swobody i poszanowania jego zdania. Co więcej, ma być to zrównoważenie, które w doborze ilości każdego z wymienionych wyżej czynników bierze pod uwagę wiek i predyspozycje indywidualne konkretnego dziecka. Osiągnięcie takiego wyważonego podejścia jest niewątpliwie bardzo trudne, ale na szczęście w obliczu takiego wyzwania z pomocą przychodzi postawa Maryi ukazana w końcowej części analizowanej perykopy. Wobec niełatwych i niezrozumiałych słów Jezusa (por. Łk 2,50) „Matka Jego chowała wiernie wszystkie te wspomnienia w swym sercu" (Łk 2,51b). Nie chodzi tu tylko o tworzenie czegoś w rodzaju „wewnętrznego pamiętnika”, lecz o coś znacznie ważniejsze-

15 Por. M. Bednarz, Duszpasterski komentarz do Nowego Testamentu. Ewangelia wg św. Łukasza (Łk 1,1-12,59), s. 82n.

16 Por. F. Mickiewicz, Ewangelia według świętego Łukasza rozdziały 1-11, s. 205n. 
go - o duchowe rozważanie i medytowanie ${ }^{17}$ nad niezwykłymi wydarzeniami związanymi z jej dzieckiem, nad Jego misją i powołaniem ${ }^{18}$. Przykład Maryi wskazuje więc, że jeśli rodzice chcą stworzyć naprawdę sprzyjające warunki dla rozwoju swojej pociechy, to muszą podjąć na modlitwie refleksję nad swoim dzieckiem, nad tym kim ono jest, jakie ma talenty i jak zachowuje się w różnych sytuacjach.

Podsumowując omawianą perykopę, warto także zauważyć, iż Jezus udzielając Józefowi i Maryi tej głębokiej odpowiedzi dotyczącej swojej misji, staje się dla nich nauczycielem. Zatem i chrześcijańscy rodzice powinni być otwarci na to, że mogą się niejednej mądrej rzeczy nauczyć od własnego dziecka, i to mimo jego pozornej niedojrzałości. Stąd wypływa olbrzymia wartość rozmów z dzieckiem, które przynoszą dobre owoce dla każdej ze stron. Co więcej, Maryja, przyjmująca milczeniem słowa Syna ${ }^{19}$, uczy, że ojciec z matką niekoniecznie muszą mieć zawsze ostatnie zdanie. Takie wspólne dialogi, pełne szacunku i wzajemnego wysłuchania, mogą pozwalać na osiągnięcie rozwiązań satysfakcjonujących wszystkich członków rodziny.

Następnym fragmentem wartym przyjrzenia się, jest summarium o dorastaniu Jezusa, który to tekst stanowi przejście do początku opisu Jego publicznej działalności: „Jezus zaś czynił postępy w mądrości, w latach i w łasce u Boga i u ludzi” $(Ł k 2,52)^{20}$. Szczególnie warte wyjaśnienia jest wyrażenie $\pi \rho \circ \varepsilon ́ \kappa о \pi \tau \varepsilon v$

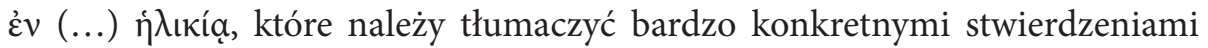
„rozwijał się fizycznie”, „wzrastał fizycznie”, a nie ogólnym niewiele mówiącym wyrażeniem „postępował w latach", jak to ma miejsce w Biblii Tysiąclecia ${ }^{21}$. Zatem to summarium mówi o rozwoju intelektualnym (postępował w mądrości), o wzroście fizycznym, a także duchowym i społecznym dojrzewaniu Jezusa (postępował w łasce - życzliwości u Boga i u ludzi). Ewangelia w ten sposób

17 Takie pełniejsze znaczenie słów o „wiernym zachowywaniu w sercu tych wspomnień" nasuwa paralelny werset Łk 2,19, będący podsumowaniem wydarzeń związanych z narodzeniem Jezusa: „Lecz Maryja zachowywała wszystkie te sprawy i rozważała je w swoim sercu".

18 Por. H. Langkammer, Komentarz do Ewangelii wg św. Łukasza i Ewangelii wg św. Jana, s. 44n.

19 Tekst analizowanej perykopy nic nie mówi o jakiejkolwiek odpowiedzi Józefa czy Maryi na słowa Jezusa, wyrażające Jego zdziwienie urządzonymi poszukiwaniami i wskazujące na konieczność przebywania „w tym, co należy do Ojca” (por. Łk 2,49-51).

20 Jest to drugie $\mathrm{z}$ dwóch takich Ewangelicznych podsumowań. Pierwsze z nich dotyczyło młodszych lat Jezusa: „Dziecię zaś rosło i nabierało mocy, napełniając się mądrością, a łaska Boża spoczywała na Nim” (Łk 40). Oba zasadniczo nie różnią się co do przesłania, choć drugie wydaje się być trochę bogatsze treściowo i dlatego jest dokładniej omawiane.

21 Por. F. Mickiewicz, Ewangelia według świętego Łukasza rozdziały 1-11, s. 206. 
pokazuje, że rozwijał się On jak każde zwykłe dziecko, które powinno mieć zapewnione warunki do integralnego całościowego rozwoju, obejmującego wszystkie dziedziny życia i dostosowanego do wieku i potrzeb młodego człowieka ${ }^{22}$.

\section{Podejście dorosłego Jezusa do dzieci}

Kolejna scena, cenna dla tematu wychowania dzieci, ukazuje już dorosłego Jezusa podczas jego działalności publicznej. Chrystus dla pouczenia swoich uczniów, stawia im przed oczyma dziecko, a ma to miejsce w sytuacji, gdy zaczynają oni myśleć o tym, który z nich jest największy (Mt 18,1-5; Mk 9,33-37; $Ł k$ 9,46-48 ${ }^{23}$. Wtedy Chrystus „wziął dziecko, postawił je przy sobie i rzekł do nich: Kto przyjmie to dziecko ${ }^{24} \mathrm{w}$ imię moje, Mnie przyjmuje; a kto Mnie przyjmie, przyjmuje Tego, który Mnie posłał" (Łk 9,47b-48a). Mamy tu do czynie-

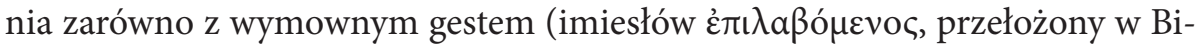
blii Tysiąclecia formą czasownikową „wziął”, może być także tłumaczony jako „ująwszy”), jak i z ciepłymi, doceniającymi dzieci słowami. Użyty przez Jezusa termin $\pi$ aı $\delta$ íov oznacza malutkie dziecko, dzieciątko - zatem takie, które wymaga dużo opieki, troski i poświęcenia mu czasu. Tak więc za wzór stawiani są ci, którzy przyjmują dzieci, czy też mówiąc szerzej, wszystkich tak bezbronnych i słabych jak one. Gdy czynią to ze względu na Jezusa („w imię Moje”), wówczas przyjmują Go samego, a wraz z Nim i Ojca („Tego, który Mnie posłał”). Co

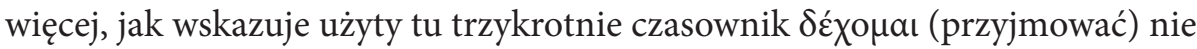
chodzi tu tylko o fizyczny gest przygarnięcia, ale o egzystencjalną, duchową postawę przyjmowania. Zatem można stwierdzić że religijna motywacja otwartości na dzieci oraz na służbę słabym i potrzebującym pomocy, jest nagradzana

22 Por. M. Bednarz, Duszpasterski komentarz do Nowego Testamentu. Ewangelia wg św. Łukasza (Łk 1,1-12,59), s. 86n.

23 Scena ukazania dziecka za przykład do naśladowania pojawia się u wszystkich synoptyków i to zawsze w kontekście mowy o wielkości. Dla Mt charakterystyczne jest to, że uczniowie pytają kto będzie największy w Królestwie niebieskim, natomiast Mk wyróżnia fakt, iż tą rozmowę rozpoczął sam Jezus, świadomy tego, iż podczas drogi dwunastu pokłóciło się między sobą właśnie o to, kto z nich jest ważniejszy.

24 W Mk pada bardziej uniwersalne stwierdzenie „Kto przyjmuje jedno z tych dzieci” (Mk 9,37), co wskazuje na fakt, iż Jezusowi nie chodziło o przyjmowanie tego konkretnego, postawionego przed uczniami dziecka - ono zostało ukazane jedynie jako przykład reprezentujący wszystkie dzieci, czyli te istoty które potrzebują pomocy i ochrony. 
tym, co dla chrześcijanina jest największą wartością, a mianowicie bliskością z Bogiem ${ }^{25}$.

W wersji Mt niniejsza perykopa zawiera jeszcze jedno pouczenie Chrystusa: „Zaprawdę, powiadam wam: Jeśli się nie odmienicie i nie staniecie jak dzieci, nie wejdziecie do królestwa niebieskiego. Kto się więc uniży jak to dziecko, ten jest największy w królestwie niebieskim" (Mt 18,3-4). Jak wskazuje przytoczony fragment najważniejszą cechą do naśladowania ${ }^{26} \mathrm{u}$ dziecka jest uniżenie rozumiane jako pokora. Związane to jest $\mathrm{z}$ tym, że w ówczesnym społeczeństwie dziecko nie miało dużego znaczenia, a więc musiało odczuwać respekt i szacunek względem dorosłych, ale także i Boga. Aczkolwiek w postawie dziecka można także znaleźć inne pozytywne cechy godne naśladowania jak m.in. otwartość, spontaniczność, zapał i entuzjazm, które ujawniają się w różnych dziedzinach życia, ale w sposób szczególny w sferze religijności ${ }^{27}$. Uświadomienie sobie docenienia tych cech przez Chrystusa, powinno motywować chrześcijańskich rodziców do pielęgnowania takich pozytywnych, naturalnych postaw u swoich dzieci, tak by procentowały one w ich dorosłym życiu.

Innym godnym uwagi wydarzeniem jest to, gdy do Jezusa przynoszono dzieci, a uczniowie, zapewne chcąc chronić Go przed natrętnym tłumem i robionym przez niego zgiełkiem, nie chcieli ich dopuścić (por. Mt 19,13-15; Mk 10,13-16; Łk 18,15-17). Reakcją Jezusa na takie postępowanie było oburzenie i nakaz dopuszczenia dzieci do Niego, bo jak uzasadnia „do takich bowiem należy królestwo Boże” (por. Mk 10,14). To stwierdzenie przywołuje na myśl obietnicę szczęścia i zbawienia wyrażoną w Ośmiu Błogosławieństwach (por. Mt 5,3.10), która w omawianym tutaj tekście dotyczy dzieci oraz tych, którzy są do nich podobni (por. Mk 10,15) ${ }^{28}$. Po czym, jak mówi tekst, Jezus „biorąc je w objęcia, kładł na nie ręce i błogosławił je” (Mk 10,16). W geście błogosławieństwa, można dopatrywać się panującego wówczas zwyczaju przynoszenia dzieci do osób bogobojnych w celu otrzymania błogosławieństwa, aczkolwiek nie można wykluczyć, że miało ono też charakter umacniający i uzdrawiający,

25 Por. H. Langkammer, Komentarz do Ewangelii wg św. Łukasza i Ewangelii wg św. Jana, s. 124; R. Popowski, Wielki słownik grecko-polski Nowego Testamentu, s. 123.222.456.

26 K. Romaniuk zauważa, że w nauce Jezusa, jak i św. Pawła, dziecko nie zawsze stanowi pozytywny wzorzec do naśladowania (widać to choćby w przypowieści o dzieciach na rynku - por. Mt 11,16-19; Łk 7,31-35). W związku z tym autor ten dokonuje przeglądu i oceny różnych przymiotów dzieci wartych odwzorowania i podsumowuje, że jego zdaniem tą najważniejszą cechą, stanowiącą tertium comparationis, jest pragnienie i dążenie do dojrzałości. Por. K. Romaniuk, „Jeśli się nie staniecie jak dzieci...”, s. 273-276.

27 Por. A. Paciorek, Ewangelia według świętego Mateusza rozdziały 14-28, s. 205.

28 Por. R.H. Stein, Mark, s. 463. 
a wówczas rzeczą uprawnioną jest mówić tutaj o modlitwie wstawienniczej29. Zatem postawa osób - zapewne rodziców - przynoszących do Jezusa dzieci, aby nałożył na nie ręce, wyraża ich troskę oraz miłość, która w sposób szczególny ujawniała się w wielu scenach, przedstawiających błagania ojców i matek o uzdrowienie ich chorych pociech ${ }^{30}$. Jezus w trakcie swojej ziemskiej wędrówki zawsze miał czas, aby zatrzymać się i pochylić nad dziećmi, a to nasuwa wniosek, iż także i dzisiaj warto do Niego przyprowadzać najmłodszych ${ }^{31}$.

Na koniec omawiania ewangelicznych wzmianek odnoszących się do kwestii wychowania, trzeba jeszcze wskazać teksty, mówiące o olbrzymiej odpowiedzialności za dawany przykład, która spoczywa na uczniach Chrystusa. Podają one przestrogę Jezusa, by nie stać się powodem zgorszenia dla jednego z tych małych (por. Mt 18,6-7; Mk 9,42; Łk 17,1-2). Jezus używa tu stwierdzenia oí $\mu$ ıкoí - mali, co zapewne wskazuje, iż chodzi mu, mówiąc ogólnie, o słabych $\mathrm{w}$ wierze. Jednakże trzeba również zauważyć, iż to pouczenie, $\mathrm{w}$ wersji mateuszowej, wypływa z nauki Chrystusa, stawiającej dziecko za wzór. Zatem uprawnioną rzeczą jest w „tych małych”, dopatrywać się również dzieci, a nie tylko tych członków wspólnoty, którzy potrzebują umocnienia. W każdym bądź razie spowodowanie grzechu, niewierności, czy też sprokurowanie okazji

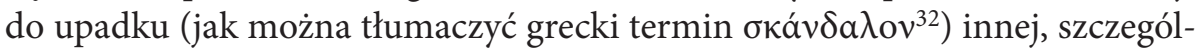
nie młodej i niewinnej osoby jest tak olbrzymią winą, że temu który się jej dopuścił lepiej by było uwiązać kamień u szyi i utopić go w morzu (por. Mt 18,6). Chcąc doprecyzować na czym mogło polegać zgorszenie, o którym mówił Jezus, trzeba zauważyć iż takim złem jest wszelkie postępowanie osłabiające wiarę innych i niszczące ich więź z Chrystusem i Kościołem ${ }^{33}$. Niniejsza perykopa ukazuje więc jak ważną rzeczą jest pozytywny przykład i jednocześnie

29 Na podobieństwo gestów błogosławienia dzieci oraz uzdrawiania wskazuje stosowanie przez Ewangelistów w obu tych przypadkach czasowników $\pi \rho \circ \sigma \varphi \varepsilon ́ \rho \omega-$ przynosić, przyprowadzać jak i å $\tau \omega \omega$ - dotykać. Warto również zauważyć, że ta druga czynność,

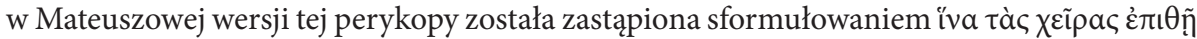

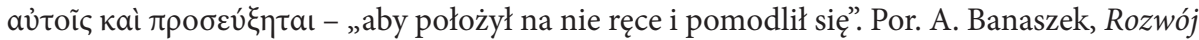
opowiadania o błogosławieniu dzieci w świetle teologicznych koncepcji synoptyków, s. 61-63.

30 Można wymienić tu choćby prośbę Jaira o uzdrowienie jego córki (por. Mt 9,18-19.23-25; Mk 5, 22-24.35-43; Łk 8,41-42.49-56), błaganie kobiety kananejskiej o uleczenie jej córki (por. Mt 15,21-28; Mk 7,24-30), uleczenie chłopca chorego na epilepsję (por. Mt 17,14-18; Mk 9,14-27; Łk 9,38-43a), czy też uzdrowienie syna urzędnika królewskiego (por. J 4,46-53).

31 Por. D.A. Hagner, Matthew 14-28, s. 553.

32 Por. R. Popowski, Wielki słownik grecko-polski Nowego Testamentu, s. 556.

33 Por. F.D. Bruner, Matthew, t. 2, s. 213; J. Homerski, Ewangelia według św. Mateusza, s. 264. 
jak niezmiernie destruktywne jest antyświadectwo. Podkreślić trzeba także, że wezwanie to dotyczy wszystkich chrześcijan, a w sposób wyjątkowy rodziców, gdyż to oni mają największy wpływ na kształtowanie dzieci - czyli tych, którzy są najbardziej podatni na zewnętrzne wzorce.

\section{Zakończenie}

Zbierając wyniki powyższych analiz, trzeba zauważyć, iż ta stosunkowo niewielka ilość ewangelicznych tekstów, poruszających zagadnienie wychowania dzieci, niesie dość spore bogactwo treści, mogących stać się pomocą i inspiracją dla chrześcijańskich rodziców. Postawę ojca i matki oczywiście powinna cechować miłość, ta zaś ma się wyrażać poprzez staranną opiekę nad dziećmi, przez poszanowanie ich zdania i okazywane im zrozumienie, czy też poprzez pielęgnowanie tego, co w człowieku dobre i naturalne, jak np. otwartość czy spontaniczność. Ważną rzeczą jest też edukacja religijna najmłodszych, polegająca m.in. na przyprowadzaniu ich do Chrystusa, tak, by już od najwcześniejszych lat kształtowała się ich żywa relacja z Bogiem.

Tego typu działania pozwolą na prawidłowy, integralny i całościowy rozwój potencjału dzieci. Jednak żeby te wszystkie starania były przeprowadzone w sposób właściwy i przyniosły dobry skutek, potrzebna jest refleksja modlitewna małżonków, połączona $\mathrm{z}$ ich głęboką wiarą, prowadzącą ich przez życie. Taka prawdziwie religijna postawa pomoże im też ustawić w swojej rodzinie właściwą hierarchię wartości, bo wśród wielu słów Jezusa znajdują się także i te: „Kto kocha ojca lub matkę bardziej niż Mnie, nie jest Mnie godzien. I kto kocha syna lub córkę bardziej niż Mnie, nie jest Mnie godzien” (Mt 10,37). Tak więc rodzice $\mathrm{z}$ jednej strony powinni być świadomi, iż $\mathrm{w}$ relacji do dzieci są tylko zastępcami Boga i nie mają nad nimi władzy absolutnej, a z drugiej, że też dziecko nie może zająć w ich życiu pierwszego miejsca, które przynależy się Bogu i wszystko, co człowiek czyni powinno być podejmowane ze względu na Niego Samego. Zatem dla małżonków rodzicielstwo jest powołaniem i drogą do świętości, a wychowanie przez nich potomstwa staje się jakże ważnym procesem kształcenia nowych uczniów Chrystusa. Warto więc podejmować taki trud, wysiłek i wyrzeczenia, okazywać troskę oraz starać się, bo oprócz nadprzyrodzonej perspektywy przebywania i komunii z Bogiem, tu na ziemi nie ma większej inwestycji niż inwestycja w człowieka. 


\section{Bibliografia}

Abogunrin S.O., Ewangelia według św. Łukasza, w: Międzynarodowy komentarz do Pisma Świętego. Komentarz katolicki i ekumeniczny na XXI wiek, W.R. Farmer (red.), Warszawa 2000, s 1239-1299.

Banaszek A., Rozwój opowiadania o błogosławieniu dzieci w świetle teologicznych koncepcji synoptyków (Mk 10,13-16; Mt 19,13-15; Łk 18,15-17), w: „Pan moim światłem". Księga pamiątkowa dla Księdza Profesora Jerzego Chmiela w 65. rocznice urodzin, W. Chrostowski (red.), Warszawa 2000, s. 48-78.

Bednarz M., Duszpasterski komentarz do Nowego Testamentu. Ewangelia wg św. Łukasza (Łk 1,1-12,59), Tarnów 2008.

Bruner F.D., Matthew. A Commentary, Grand Rapids 2004, 2 tomy.

Gauthier R., Święty Józef w Historii Zbawienia. Rys Biblijno-Teologiczny, Ateneum Kapłańskie 71 (1978), t. 90, z. 1, s. 32-43.

Hagner D.A., Matthew 14-28, Dallas 1995.

Herrmann T., Obowiązki rodziców względem dzieci w Nowym Testamencie, Ruch Biblijny i Liturgiczny 14 (1961), nr 1-2, s. 43-52.

Homerski J., Ewangelia według św. Mateusza. Wstęp - przekład z oryginału, komentarz, Poznań-Warszawa 1979.

Jankowski A., Matka Mesjasza pierwowzorem Kościoła. Nowe drogi i próby syntez mariologii biblijnej, Ateneum Kapłańskie 56 (1964), t. 67, z. 4, s. 209-219.

Jankowski A., Początki Łukaszowej Mariologii, Ruch Biblijny i Liturgiczny 41 (1988), nr 4, s. 320-329.

Johnson L.T., The Gospel of Luke, Collegeville 1991.

Keener C.S., Komentarz historyczno-kulturowy do Nowego Testamentu, Warszawa 2000.

Królikowski J., Biblijne miejsce Józefologii, Ruch Biblijny i Liturgiczny 47 (1994), nr 1, s. $42-48$.

Langkammer H., Komentarz do Ewangelii wg św. Łukasza i Ewangelii wg św. Jana, Poznań 2014.

Łach J., Ewangelie dziecięctwa - historia czy legenda?, Ateneum Kapłańskie 74 (1982), t. 99 , z. 2, s. 304-316.

Mickiewicz F., Ewangelia według świętego Łukasza rozdziały 1-11. Wstęp, przekład $z$ oryginału, komentarz, Częstochowa 2011.

Nolland J., Luke 1-9:20, Dallas 1989.

Paciorek A., Ewangelia według świętego Mateusza rozdziały 1-13. Wstęp, przekład z oryginału, komentarz, Częstochowa 2005.

Paciorek A., Ewangelia według świętego Mateusza rozdziały 14-28. Wstęp, przekład $z$ oryginału, komentarz, Częstochowa 2008.

Popowski R., Wielki słownik grecko-polski Nowego Testamentu, Warszawa 1994.

Romaniuk K., „Jeśli się nie staniecie jak dzieci...”, Homo Dei 47 (1978), s. 273-276.

Romaniuk K., Jankowski A., Stachowiak L., Komentarz praktyczny do Nowego Testamentu, Poznań-Kraków 1999, 2 tomy.

Stein R.H., Mark, Grand Rapids 2008.

Szlaga J., Główne tematy w Ewangelii Jezusa Chrystusa, Ruch Biblijny i Liturgiczny 32 (1979), nr 2-3, s. 90-104. 